\title{
Citrulline deiminase pathway provides ATP and boosts growth of Clostridium carboxidivorans P7
}

\author{
Xiangfei Li ${ }^{1}$, Rumeng Han ${ }^{1}$, Teng Bao ${ }^{2}$, Tolbert Osire ${ }^{1}$, Xian Zhang ${ }^{1}$, Meijuan Xu' ${ }^{1}$, Taowei Yang ${ }^{1 *}$ and \\ Zhiming Rao ${ }^{*^{*}}$ (D)
}

\begin{abstract}
Background: Clostridium carboxidivorans P7 is capable of producing ethanol and butanol from inexpensive and non-food feedstock, such as syngas. Achieving improved ethanol and butanol production in the strain for industrial application depends on the energetics and biomass, especially ATP availability.

Results: This study found that exogenous addition of citrulline promoted accumulation of ATP, increased specific growth rate, and reduced the doubling time of C. carboxidivorans P7. In heterotrophic fermentation experiments, the addition of citrulline increased intracellular ATP by 3.39-fold, significantly enhancing the production of total alcohol (ethanol + butanol) by 20\%. Moreover, in the syngas fermentation experiments, the addition of citrulline improved the level of intracellular ATP and the biomass by $80.5 \%$ and $31.6 \%$, respectively, resulting in an $18.6 \%$ and $60.3 \%$ increase in ethanol and the alcohol/acid production ratio, respectively.
\end{abstract}

Conclusions: This is the first report that citrulline could promote the growth of C. carboxidivorans P7 and increase the level of intracellular ATP, which is of great significance for the use of C. carboxidivorans P7 to synthesize biofuels.

Keywords: Clostridium carboxidivorans, Citrulline, Syngas fermentation, Alcohol/acid ratio

\section{Background}

Globally, the main energy source for human survival is petroleum-based non-renewable fossil fuels [1]. Nowadays, fossil fuel depletion, increasing energy consumption, growing $\mathrm{CO}_{2}$ emissions, and climate change have increased the demand for renewable energy sources $[2$, 3]. As renewable biomass fuels, ethanol [4] and butanol [5] have high energy density and are compatible with current petroleum energy infrastructure equipment, which has attracted significant attention [6]. However, the production of bio-butanol and bio-ethanol is presently

\footnotetext{
*Correspondence: ytw1228@163.com; raozhm@jiangnan.edu.cn

${ }^{1}$ The Key Laboratory of Industrial Biotechnology, Ministry of Education,

School of Biotechnology, Jiangnan University, 1800 Lihu Road,

Wuxi 214122, Jiangsu, China

Full list of author information is available at the end of the article
}

limited owing to the high substrate cost of conventional feedstocks, such as starch and molasses [7]. In recent years, gas fermentation has attracted increasing attention as an emerging method for the production of renewable biofuels, such as bio-butanol and bio-ethanol $[8,9]$. On one hand, the feedstocks for gas fermentation are relatively abundant and inexpensive, such as exhaust gas from industrial production, and burning fossil fuels, as well as synthetic gas. On the other hand, compared with traditional acetone-butanol-ethanol (ABE) fermentation by solventogenic Clostridium, gas fermentation does not occupy food resources and precious land resources of humans [10-13]. However, low solubility of gaseous substrates in water, low ATP generation, and poor biomass of solventogenic Clostridium are still the major factors limited the production of bio-butanol and bio-ethanol $[14,15]$. original author(s) and the source, provide a link to the Creative Commons licence, and indicate if changes were made. The images or other third party material in this article are included in the article's Creative Commons licence, unless indicated otherwise in a credit line to the material. If material is not included in the article's Creative Commons licence and your intended use is not permitted by statutory regulation or exceeds the permitted use, you will need to obtain permission directly from the copyright holder. To view a copy of this licence, visit http://creativecommons.org/licenses/by/4.0/. The Creative Commons Public Domain Dedication waiver (http://creativeco mmons.org/publicdomain/zero/1.0/) applies to the data made available in this article, unless otherwise stated in a credit line to the data. 
Clostridium carboxidivorans P7 is one of the strains capable of producing biofuel from syngas [16]. It can synthesize ethanol and n-butanol by capturing $\mathrm{CO}_{2}$, $\mathrm{CO}$, and $\mathrm{H}_{2}$ through WLP (Wood-Ljungdahl pathway) [17, 18]. However, whole-genome sequencing (GenBank: CP011803.1) indicates that there is an incomplete TCA cycle in C. carboxidivorans P7 [16]. Hence, its own energy supply mainly comes from the glycolytic pathway and the synthetic pathway for acetic acid production. What is more, syngas fermentation also has drawbacks, such as low biomass and insufficient energy supply, resulting in low biofuel production and increased by-products accumulation. Although optimization of the appropriate media composition, metal ion composition [19], $\mathrm{pH}[20,21]$, and reactor design [22] can improve cell growth and product accumulation, it is not of help in increasing intracellular ATP production. Therefore, there is an urgent need to enhance intracellular ATP supply and biomass of $C$. carboxidivorans P7, so as to promote the biofuels production. Nowadays, genetic engineering is regarded as a useful strategy to manipulate the metabolism and to enhance accumulation of ideal products [23-25]. However, the molecular genetic manipulation technology of C. carboxidivorans P7 had just been established [7], it required relatively long operation time, and the success rate was not high. So, investigators have noted that amino acids, as the basic building blocks of proteins, play a crucial role in the life of cells [26]. It is known that arginine can be hydrolyzed by the action of arginase to produce urea and ornithine. The ornithine could react with carbamoyl phosphate to generate citrulline by ornithine carbamoyltransferase. Finally, citrulline can be transformed to carbon dioxide, water, ammonia, and two molecules of ATP by carbamoyl phosphate synthetase [27]. The addition of arginine shortened the Clostridium autoethanogenum doubling time, increased the intracellular ATP energy level by fivefold, and weakened the accumulation of by-product acetic acid [15]. Therefore, amino acid metabolism has an enormous potential to improve the cell density and intracellular energy level of C. carboxidivorans P7.

This paper assessed the significance of amino acids which could be helpful to promote the biomass, ATP regeneration, and the yield of biofuels. It was found that citrulline could provide additional ATP and enhance biomass and specific growth rate for C. carboxidivorans P7 under both heterotrophic and autotrophic conditions. What is more, the addition of citrulline increased the alcohol/acid production ratio by $60.3 \%$ under autotrophic conditions. The results provided a new method of thinking for promoting cell growth and increasing energy levels in C. carboxidivorans P7.

\section{Results}

\section{Citrulline boosted cell growth under heterotrophic} conditions

Amino acids, as the basic units of proteins, play a crucial role in cell life [26]. To explore the importance of amino acid addition for cell growth of $C$. carboxidivorans $\mathrm{P} 7$, the effects of 20 conventional amino acids on cell growth were studied by serum bottle fermentation in MM520 medium. Fermentation results showed that histidine and aspartic acid promoted cell growth, but the presence of arginine significantly impaired cell growth (Fig. 1A). It was speculated that arginase (EC: 3.5 .3 .1 ) probably converted arginine to urea and ornithine, which consequently may have contributed to increase in the metabolic load of cells and decreased cell growth. KEGG analysis revealed that C. carboxidivorans $\mathrm{P} 7$ lost the ability to yield citrulline from arginine due to the absence of arginine deiminase. We hypothesized that if cells could generate citrulline from arginine, they could then break down arginine through the ADI (arginine deiminase) pathway, hence providing cells with additional ATP supply. Although the complete ADI metabolic pathway does not exist in C. carboxidivorans $\mathrm{P} 7$, it does have a complete citrulline degradation pathway. Furthermore, it was known that citrulline could be transformed to carbon dioxide, water, ammonia, and two molecules of ATP by carbamoyl phosphate synthetase [27]. Therefore, citrulline was added to explore the effects on the cell density of $C$. carboxidivorans P7. The results indicated that the addition of citrulline significantly promoted the growth capacity of C. carboxidivorans $\mathrm{P} 7$, and the maximum $\mathrm{OD}_{600}$ increased by $18.6 \%$ compared with the wild-type strain (Fig. 1A).

To further determine the optimal concentration of citrulline addition, $0.6 \mathrm{~g} / \mathrm{L}, 1.2 \mathrm{~g} / \mathrm{L}$, and $2.4 \mathrm{~g} / \mathrm{L}$ citrulline were added to the fermentation medium and incubated under the same conditions. The results showed that the addition of $0.6 \mathrm{~g} / \mathrm{L}$ citrulline was most beneficial for cell growth. The stable phase of the cells was obviously prolonged and the sugar consumption was significantly promoted. The glucose was depleted after $24 \mathrm{~h}$ fermentation. Increasing the concentration of citrulline further resulted in decreased cell growth compared with the addition of $0.6 \mathrm{~g} / \mathrm{L}$ citrulline (Fig. 1B and C). It may be due to the limited use of citrulline by C. carboxidivorans P7. As shown in Fig. 1D, there were still a large amount of citrulline residues in the later stage of fermentation under the addition of $1.2 \mathrm{~g} / \mathrm{L}$ or $2.4 \mathrm{~g} / \mathrm{L}$ citrulline.

\section{Heterotrophic growth experiments proved that citrulline metabolism promoted cell glycolysis and delayed cell aging}

Based on the above results, the addition of citrulline boosted cell growth, accelerated glucose utilization, and prolonged cell stability. It is known that citrulline 

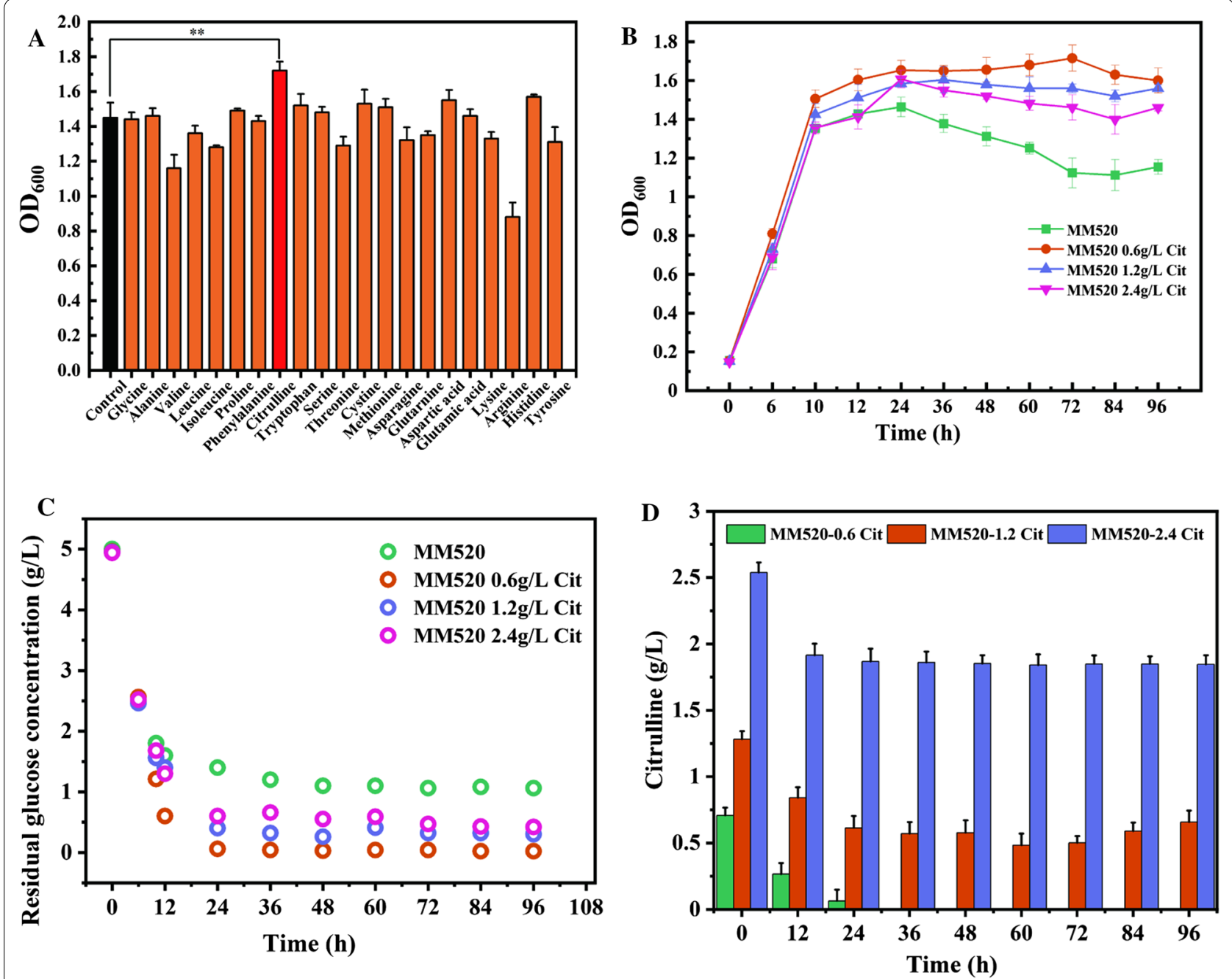

Fig. 1 Effects of different of amino acids and different concentration of citrulline on the growth of C. carboxidivorans P7. A The effects of 21 amino acids on the growth of C. carboxidivorans P7. B Effects of different concentrations of citrulline on the growth of C. carboxidivorans P7. C Effects of different concentrations of citrulline on sugar consumption of C. carboxidivorans P7. D The concentration of residual citrulline under the addition of $0.6 \mathrm{~g} / \mathrm{L}, 1.2 \mathrm{~g} / \mathrm{L}$, or $2.4 \mathrm{~g} / \mathrm{L}$ citrulline. ${ }^{* *} P<0.05$

can generate carbamoy-P under the action of ornithine carbamoyltransferase; then the carbamoy-P generates $\mathrm{CO}_{2}$ and ATP under the action of carbamate kinase (Fig. 2D). Therefore, it was speculated that citrulline catabolism provided additional ATP supply for glycolysis, thereby improving the ability of two key energyconsuming enzymes ( $g l k$ and $p f k$ ), in turn increasing glucose utilization. Under the same conditions, C. carboxidivorans $\mathrm{P} 7$ was fermented in serum bottle using MM520-0.6 Cit and MM520 medium for the same time and samples were taken regularly. RT-qPCR was used to analyze the expression levels of $g l k$ (encoding glucokinase), $p f k$ (encoding phosphofructokinase), otc (encoding ornithine carbamoyltransferase), and $c k$ (encoding carbamate kinase) at $12 \mathrm{~h}, 24 \mathrm{~h}$, and $36 \mathrm{~h}$, respectively. The results showed that in MM520-0.6 Cit medium, $g l k, p f k$, otc, and $c k$ were significantly up-regulated at $12 \mathrm{~h}, 24 \mathrm{~h}$, and $36 \mathrm{~h}$ (Fig. 2A, B, and C). However, after $24 \mathrm{~h}$ of fermentation, due to the consumption of citrulline and glucose, the relative expression of $g l k, p f k$, otc, and $c k$ decreased accordingly. After the fermentation at $96 \mathrm{~h}$, it was found that the cells cultured in MM5200.6 Cit medium had smooth surface and no residue of glucose particles observed by frozen scanning electron microscopy (FSEM) (Fig. 3B). On the contrary, the surface of cells cultured in MM520 medium had a rough surface with more glucose residues (Fig. 3A). It was also reported that cells had obvious differences in 


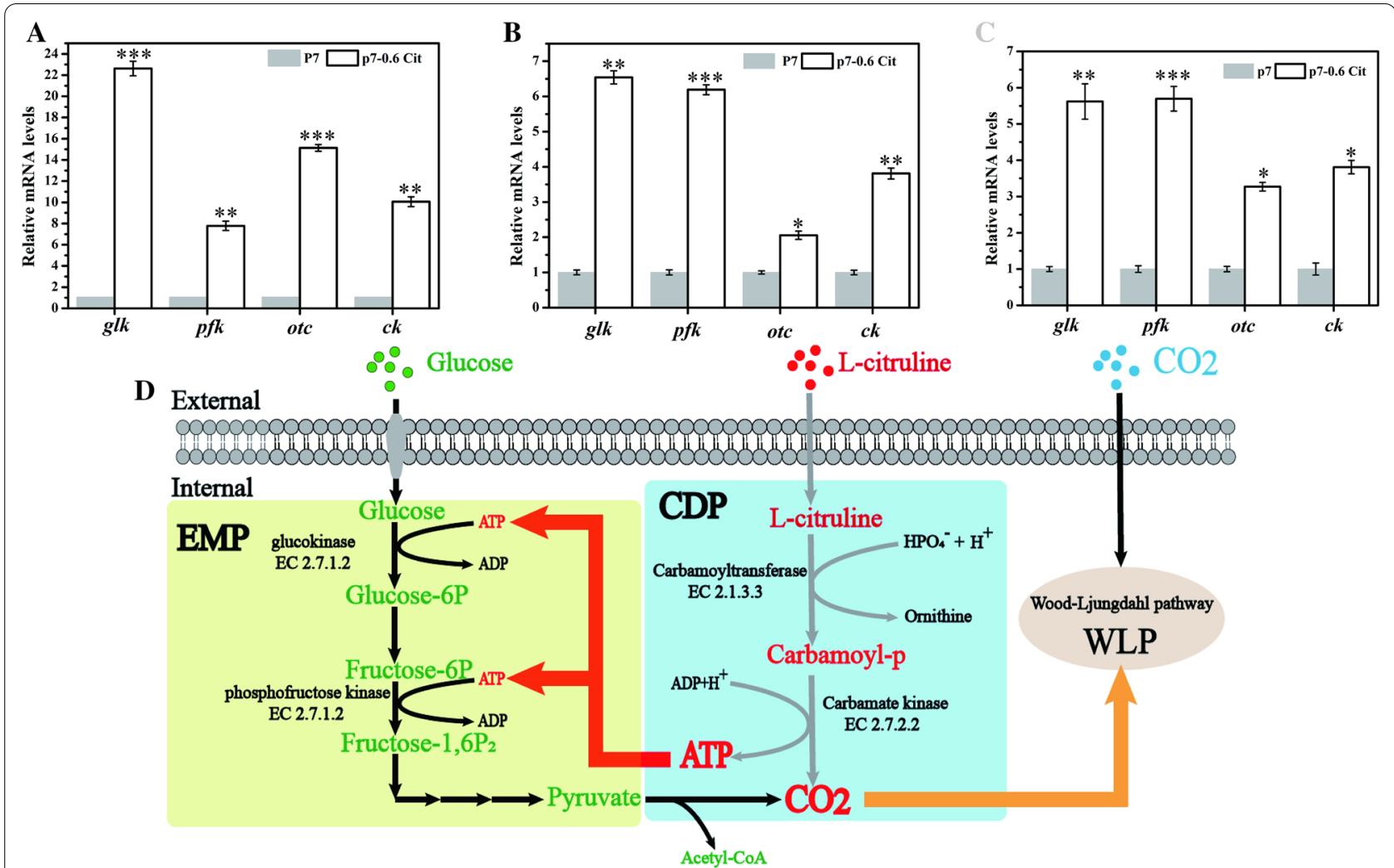

Fig. 2 Expression of key genes related to citrulline metabolism pathway and key genes of EMP pathway were analyzed by RT-qPCR during $C$. carboxidivorans P7 heterotrophic fermentation in different medium. RT-qPCR analysis of C. carboxidivorans P7 fermented for $12 \mathrm{~h}(\mathbf{A}), 24 \mathrm{~h}(\mathbf{B})$, and 36 h (C). D Citrulline metabolism pathway. (P7: C. carboxidivorans P7 was fermented in MM520 medium. P7-0.6 g/L Cit: C. carboxidivorans P7 was fermented in MM520-0.6 Cit medium.) ${ }^{*} P<0.05 .{ }^{* *} P<0.01$. ${ }^{* *} P<0.001$

cell morphology at different growth stages [12]. In the decline phase, the cell surface would become rough compared with the early phase [12]. So, it was speculated that the cell morphology may be able to reflect the growth state of the cells. As a result, the FSEM experiments also showed that cells with citrulline addition had a more smooth surface (Fig. 3B). So indicated that citrulline promoted cell viability and delayed cell aging. Therefore, FSEM analysis further showed that the addition of citrulline contributed to promote the

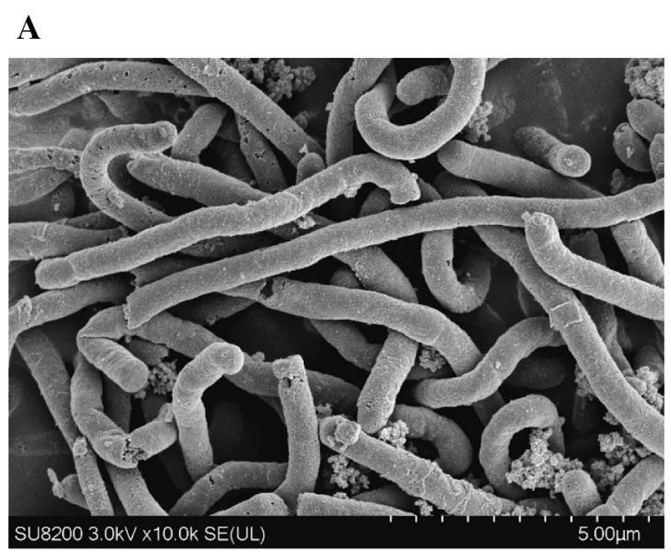

B

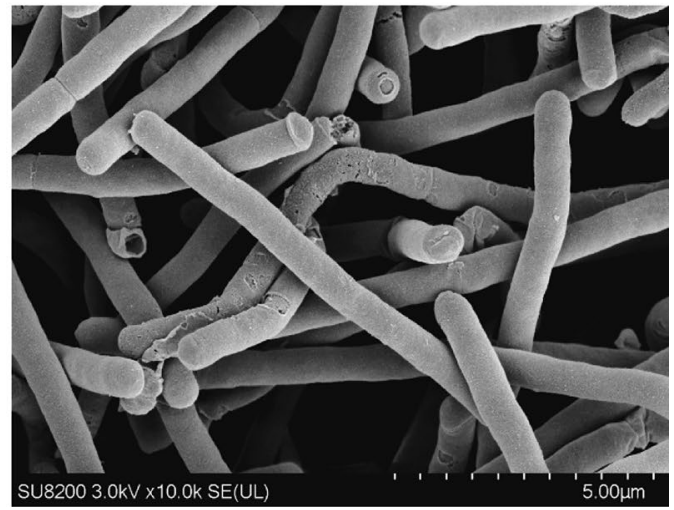

Fig. 3 FSEM analysis of C. carboxidivorans P7 fermented in MM520 medium (A) and MM520-0.6 Cit medium (B) for $96 \mathrm{~h}$ 
metabolism of glucose by C. carboxidivorans $\mathrm{P} 7$ and could maintain cell viability.

\section{Citrulline boosted heterotrophic growth of $C$. carboxidivorans P7 while supplying extra ATP}

By analyzing the metabolic pathway of citrulline, it was further speculated that citrulline catabolism could provide cells with additional ATP, thereby promoting cell growth. Therefore, under the same conditions, C. carboxidivorans P7 was fermented in serum bottles with MM520-0.6 Cit and MM520 medium for the same time. The specific growth rate, doubling time, and intracellular ATP levels of the cells were further analyzed. The results showed that the specific growth rate of $C$. carboxidivorans P7 in MM520-0.6 Cit medium increased significantly when the fermentation was performed within $10 \mathrm{~h}$ to $30 \mathrm{~h}$ (Fig. 4). It is known that citrulline can be transformed to carbon dioxide, water, ammonia, and two molecules of ATP by carbamoyl phosphate synthetase. What is more, it was also shown that citrulline addition promoted the utilization of glucose (Fig. 1C). As a result, the addition of citrulline provided additional ATP and enhanced glucose consumption. However, the increase in glucose consumption would also produce more acids. So, acids were increased when citrulline was added (Fig. 4F). When fermentation reached $30 \mathrm{~h}$, the cell doubling time of C. carboxidivorans P7 in MM520-0.6 Cit medium was
$162 \mathrm{~h}$, which was $81.3 \%$ shorter than that of MM520 medium. Through analysis of intracellular ATP level, it was found that the ATP level in MM520-0.6 Cit medium was 3.39-fold higher than that in MM520 medium at $24 \mathrm{~h}$. In addition, it was reported that the addition of arginine increased the intracellular energy ATP level by fivefold in C. autoethanogenum [15]. Metabolic modeling and experiments also showed increased in ATP production through the arginine deiminase pathway [15]. It should be noted that the mechanism of arginine metabolism to promote ATP accumulation is similar as that of citrulline metabolism. Therefore, it was believed that the higher ATP level was contributed with citrulline addition. The results herein showed that the addition of citrulline increased intracellular ATP levels under heterotrophic conditions. Thereafter, when citrulline was depleted, the intracellular ATP level decreased and remained at a lower level.

Under heterotrophic conditions, metabolites of C. carboxidivorans P7 in MM520 and MM520-0.6 Cit medium were analyzed (Table 1 ). The addition of citrulline had no significant effect on product conversion of ethanol and butanol. However, the addition of citrulline could promote the utilization rate of glucose in cells. Although the product conversion rate did not change significantly, the total alcohol yield of fermentation products (the yield of
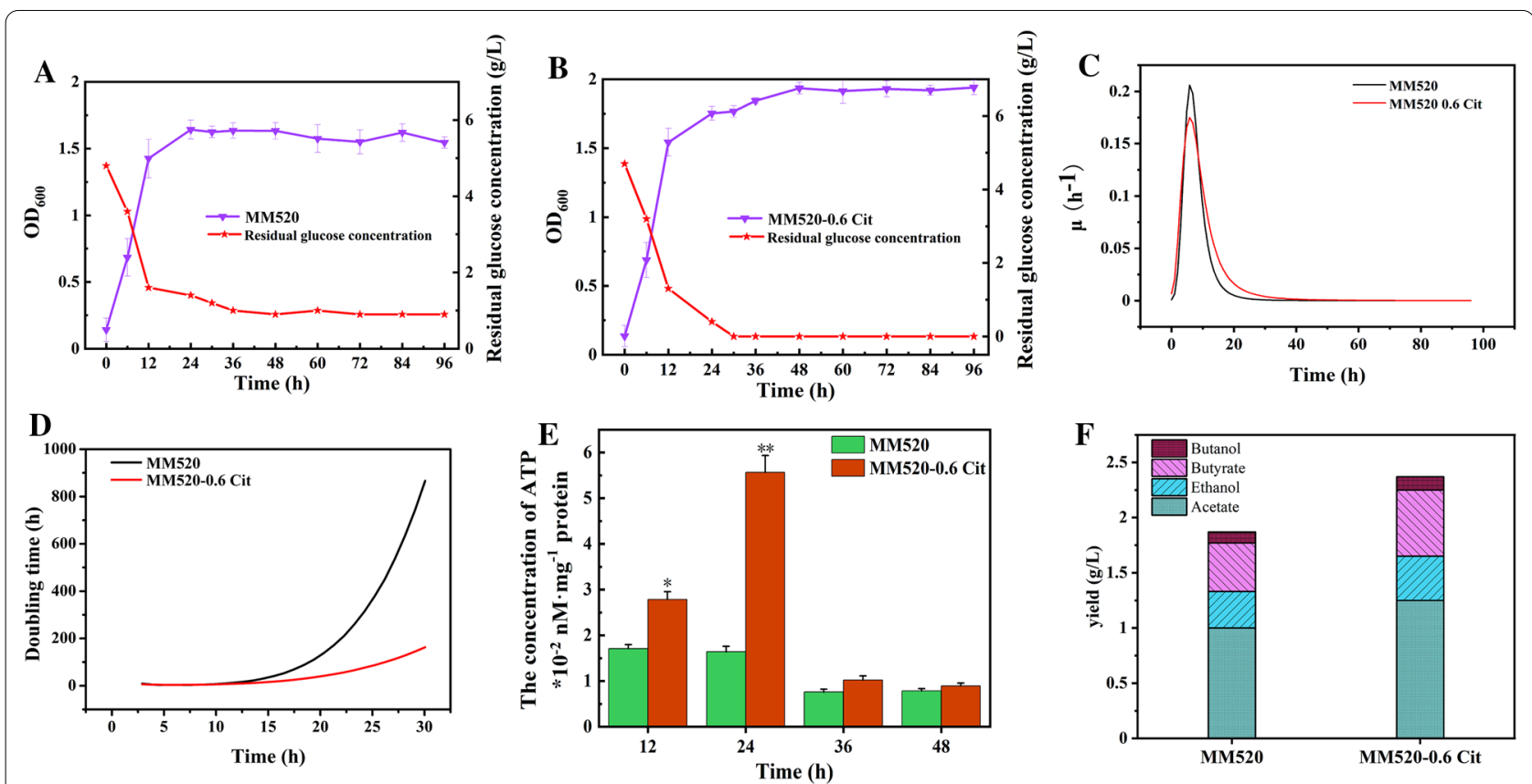

Fig. 4 Under heterotrophic conditions, the effects of citrulline on the fermentation of C. carboxidivorans P7. C. carboxidivorans P7 was cultivated in MM520 medium (A) and MM520-0.6 Cit medium (B). C Doubling time, D Specific growth rate, (E) The concentration of ATP. F The yield of ethanol, butanol, acetate, and butyrate in heterotrophic conditions. ${ }^{*} P<0.05 .{ }^{*} P<0.01$ 
Table 1 Under heterotrophic conditions, the product yields of C. carboxidivorans P7 under different culture conditions

\begin{tabular}{|c|c|c|c|c|c|c|c|c|c|}
\hline Medium & Acetate $(\mathrm{g} / \mathrm{g})$ & Ethanol $(g / g)$ & $\begin{array}{l}\text { Butyrate } \\
(\mathrm{g} / \mathrm{g})\end{array}$ & $\begin{array}{l}\text { Butanol } \\
\text { (g/g) }\end{array}$ & $\begin{array}{l}\text { Total } \\
\text { alcohols } \\
(\mathbf{g} / \mathbf{g})\end{array}$ & $\begin{array}{l}\text { Total acid } \\
\text { (g/g) }\end{array}$ & $\begin{array}{l}\text { Alcohols/ } \\
\text { acids (g/g) }\end{array}$ & $\mathrm{C} 4 / \mathrm{C} 2(\mathrm{~g} / \mathrm{g})$ & $\begin{array}{l}\text { C recovery } \\
(\%)\end{array}$ \\
\hline MM520 & $0.30 \pm 0.01$ & $0.07 \pm 0.01$ & $0.15 \pm 0.01$ & $0.025 \pm 0.002$ & $0.10 \pm 0.01$ & $0.46 \pm 0.04$ & 0.21 & 0.47 & 57 \\
\hline $\begin{array}{l}\text { MM520-0.6 } \\
\text { Cit }\end{array}$ & $0.29 \pm 0.02$ & $0.08 \pm 0.01$ & $0.16 \pm 0.01$ & $0.024 \pm 0.001$ & $0.10 \pm 0.01$ & $0.45 \pm 0.02$ & 0.22 & 0.49 & 56.4 \\
\hline
\end{tabular}

ethanol and butanol was $1.2 \mathrm{~g} / \mathrm{L}$ and $0.16 \mathrm{~g} / \mathrm{L}$, respectively) increased by about $20 \%$ (Fig. 4F).

\section{Citrulline boosted autotrophic growth of $C$. carboxidivorans P7 while supplying extra ATP}

To further verify whether citrulline could provide cells with ATP and promote cell growth under autotrophic conditions $\left(\mathrm{CO}_{2} / \mathrm{CO} / \mathrm{H}_{2}\right.$ [50:35:15], $\left.1 \mathrm{~atm}\right)$, C. carboxidivorans $\mathrm{P} 7$ was fermented in Syngas-GY free and Syngas-0.6 Cit-GY free medium $\left(\mathrm{pH} 6.6,37^{\circ} \mathrm{C}, 150 \mathrm{rpm}\right)$ and the effects of citrulline improved the growth of C. carboxidivorans P7 was investigated. Firstly, as shown in Fig. 5A, when citrulline was added to the $\mathrm{N}_{2}$-GY free medium, the cells could not grow normally, indicating that citrulline could not be used as the only carbon source to maintain cell growth. However, under syngas conditions, exogenous addition of citrulline could increase the biomass of C. carboxidivorans $\mathrm{P} 7$ by $31.6 \%$. It was also found that the ATP levels in Syngas-0.6 Cit-GY free medium were significantly higher than those in Syngas-GY free medium after fermentation for $48 \mathrm{~h}$. Moreover, at $96 \mathrm{~h}$ of fermentation, although the ATP levels in Syngas-0.6 Cit-GY free medium remained almost constant, intracellular ATP levels increased $80.5 \%$ in Syngas-0.6 CitGY free medium compared to Syngas-GY free medium (Fig. 5B). It was also found that the specific growth rate of C. carboxidivorans P7 in Syngas-0.6 Cit-GY free medium increased significantly, while the doubling time of the bacteria greatly shortened after the fermentation reached $40 \mathrm{~h}$ (Fig. 5C and D).

Under autotrophic conditions, the metabolites of $C$. carboxidivorans P7 were analyzed in Syngas-0.6 Cit-GY free and Syngas-GY free medium (Table 2). The addition of citrulline increased the yield of ethanol and the alcohol/acid ratio by $18.6 \%$ and $60.3 \%$, respectively. Although the yield of ethanol reached $1.21 \mathrm{~g} / \mathrm{L}$, there was no significant change in butanol production. A possible explanation could be that the low production of butanol in $C$. carboxidivorans $\mathrm{P} 7$.

\section{Discussion}

The WLP pathway exists in C. carboxidivorans P7, which has been found in most acetic bacteria, such as Acetobacterium woodii [28], Clostridium formicoaceticum [29],
Clostridium aceticum [30], Clostridium ljungdahlii [31], and $C$. autoethanogenum [32]. Conforming to the current mainstream of clean energy, C. carboxidivorans $\mathrm{P} 7$ is able to produce biofuels from syngas via the WLP pathway. However, C. carboxidivorans P7 has low cell density and insufficient intracellular energy supply during the syngas fermentation process, rendering it industrially ineffective. In this study, it was found that the addition of citrulline not only improved cell density but also enhanced the intracellular ATP level in C. carboxidivorans P7 under both heterotrophic and autotrophic conditions. Moreover, the addition of citrulline increased the yield of ethanol and the alcohol/acid ratio by $18.6 \%$ and $60.3 \%$, respectively. Therefore, this research revealed that the exogenous addition of citrulline increased the biomass and ATP supply, which had important implications for accumulating biofuels in C. carboxidivorans P7.

Recently, cell immobilization technology, optimization of fermentation parameters, and metabolic engineering have been used to improve cell density and intracellular ATP level. Cell recovery [33] and cell immobilization [34] techniques promoted cell density during the period of fermentation, resulting in a fivefold increase in butanol production. The control of fermentation processes, such as $\mathrm{pH}[20]$, temperature [35, 36], pressure [20], and inoculation amount [37], also had a great influence on cell density, but was not reported to significantly promote the accumulation of intracellular energy ATP. Amino acids are essential elements for life [38], and amino acid metabolism can produce carbon dioxide and other small molecules for cell life activities [13]. Therefore, addition of $5 \mathrm{~g} / \mathrm{L}$ arginine [15] not only increased the cell density of $C$. autoethanogenum but also increased the intracellular energy ATP level by fivefold. The engineering modification of strains is also of great significance for improving cell fermentation density and intracellular energy ATP accumulation. Ferredoxin oxidoreductase (AOR) [39] provided extra ATP supply for acetic acid bacteria and promoted the accumulation of ethanol and butanol. $C$. autoethanogenum [16] explored the AOR/ADH pathway to increase the level of intracellular energy ATP and increase the yield of ethanol. Overexpression of two glycerol dehydrogenase (GldH) genes (dhaD1 and gldA1) in Clostridium pasteurianum further resulted in a $43 \%$ 

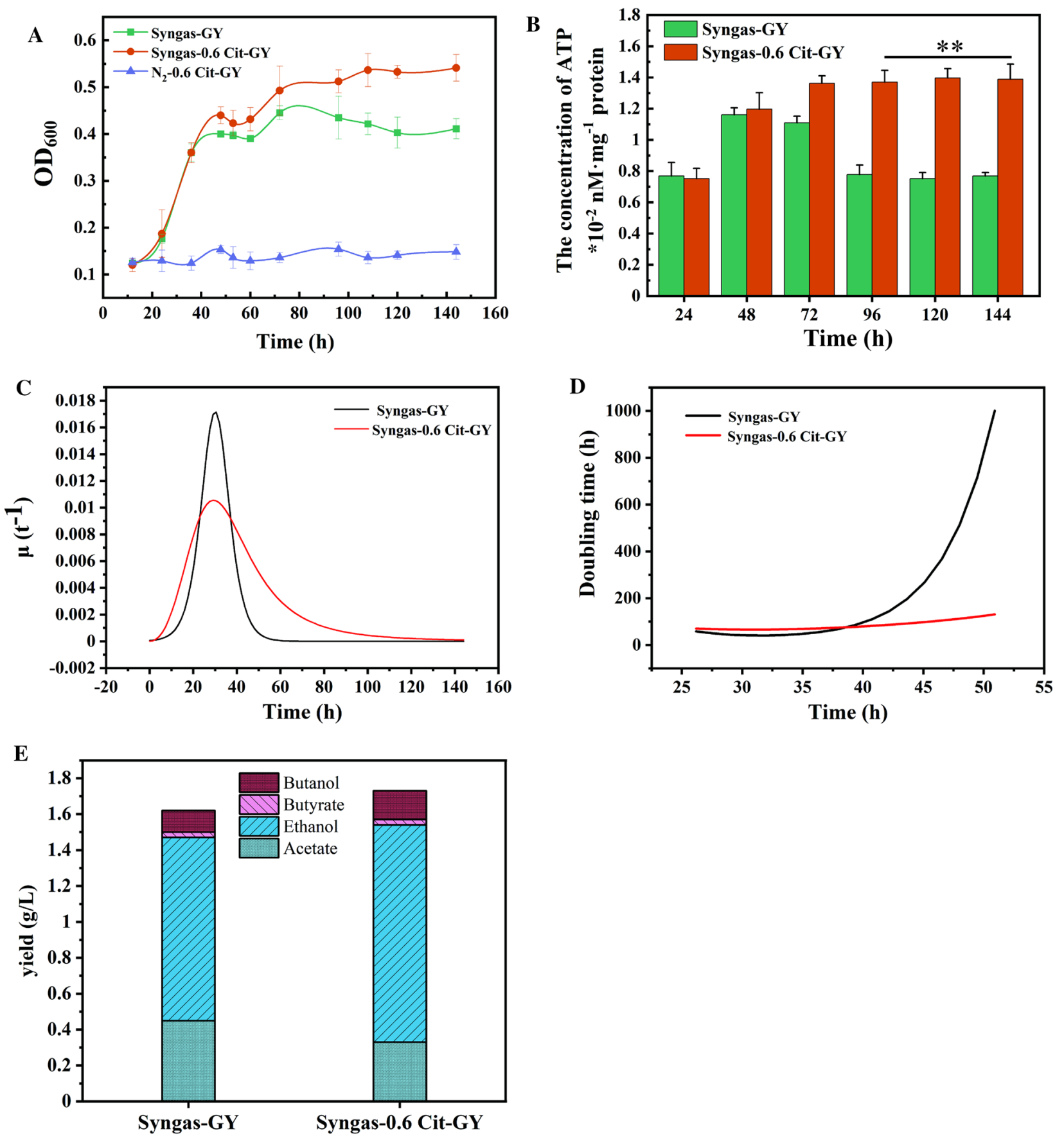

Fig. 5 Under autotrophic conditions, the effects of citrulline on the fermentation of C. carboxidivorans P7. A Cell density, B The concentration of ATP, C Specific growth rate, D Doubling time. E The yield of ethanol, butanol, acetate, and butyrate in autotrophic conditions. ${ }^{* *} P<0.01$

Table 2 Under autotrophic conditions, the product yields of C. carboxidivorans P7 under different culture conditions

\begin{tabular}{lllllllll}
\hline Medium & Acetate (g/L) & Ethanol (g/L) & Butyrate (g/L) & Butanol (g/L) & Total alcohols (g/L) & Total acid (g/L) & $\begin{array}{l}\text { Alcohols/ } \\
\text { Acids } \\
(\mathbf{g} / \mathbf{g})\end{array}$ \\
& & & & & & & & \\
\hline Syngas-GY & $0.45 \pm 0.05$ & $1.02 \pm 0.11$ & $0.12 \pm 0.03$ & $0.03 \pm 0.01$ & $1.05 \pm 0.12$ & $0.57 \pm 0.08$ & 1.84 & 0.10 \\
Syngas-0.6 Cit-GY & $0.26 \pm 0.04$ & $1.21 \pm 0.09$ & $0.16 \pm 0.02$ & $0.03 \pm 0.01$ & $1.24 \pm 0.10$ & $0.42 \pm 0.06$ & 2.95 & 0.13 \\
\hline
\end{tabular}


increase in glycerol utilization and a significant increase in cell density (>50\%) [40]. At present, the genetic operation system of C. carboxidivorans $\mathrm{P} 7$ has been preliminarily established [7]. However, there are some problems, such as complex operation, low transduction efficiency, and time consuming, making it difficult to operate in practice. Therefore, cell immobilization and optimization of fermentation parameters are still the main means to improve cell density and intracellular energy ATP supply.

Although this study achieved a synchronous increase in cell density and intracellular energy ATP of C. carboxidivorans $\mathrm{P} 7$ by exogenous addition of citrulline, the cell utilization of citrulline was not very high. Furthermore, since the genetic operation system of $C$. carboxidivorans P7 is relatively complex and inefficient, it is possible to overexpress the two key enzymes (ornithine carbamoyltransferase (OTC) and carbamate kinase (CK)) of the citrulline pathway in C. carboxidivorans $\mathrm{P} 7$, to expand the pathway of citrulline metabolism and further improve citrulline utilization of C. carboxidivorans P7.

\section{Conclusions}

In general, citrulline could promote the accumulation of intracellular energy ATP, increase the specific growth rate, and shorten the doubling time of $C$. carboxidivorans P7 under both autotrophic and heterotrophic conditions. Under heterotrophic conditions, the addition of citrulline increased the level of intracellular ATP and the production of total alcohol by 3.39 -fold and $20 \%$, respectively. Under autotrophic conditions, the addition of citrulline increased the level of intracellular ATP by $80.5 \%$, the yield of ethanol by $18.6 \%$, and the alcohol/acid ratio by $60.3 \%$. In summary, this is the first report to reveal that citrulline could promote the growth of C. carboxidivorans P7 and increase intracellular energy ATP, which is of great significance for improving the production of clean energy, such as ethanol and butanol by C. carboxidivorans P7.

\section{Methods}

\section{Strains and culture medium}

The strains and primers in the work are summarized in Table 3. C. carboxidivorans P7 (DSM 15243) was preserved at $-80{ }^{\circ} \mathrm{C}$ in our laboratory. It was inoculated into the MM520 medium, containing $\mathrm{K}_{2} \mathrm{HPO}_{4} 2.2 \mathrm{~g} / \mathrm{L}$, $\mathrm{KH}_{2} \mathrm{PO}_{4} 1.5 \mathrm{~g} / \mathrm{L},\left(\mathrm{NH}_{4}\right)_{2} \mathrm{SO}_{4} 1.3 \mathrm{~g} / \mathrm{L}$, yeast extract $2 \mathrm{~g} / \mathrm{L}$, tryptone $4 \mathrm{~g} / \mathrm{L}$, Na-Resazurin solution $0.1 \%(\mathrm{w} / \mathrm{v})$, L-cysteine- $\mathrm{HCl} \cdot \mathrm{H}_{2} \mathrm{O} 0.5 \mathrm{~g} / \mathrm{L}, \mathrm{FeSO}_{4} \cdot 7 \mathrm{H}_{2} \mathrm{O} 0.00125 \mathrm{~g} / \mathrm{L}$, $\mathrm{CaCl} \cdot 2 \mathrm{H}_{2} \mathrm{O} 0.075 \mathrm{~g} / \mathrm{L}, \mathrm{MgCl}_{2} \cdot 6 \mathrm{H}_{2} \mathrm{O} 0.2 \mathrm{~g} / \mathrm{L}$, and trace element solution $\left(\mathrm{FeCl}_{2} \cdot 4 \mathrm{H}_{2} 01.5 \mathrm{mg} / \mathrm{L}, \mathrm{ZnCl}_{2} 0.07 \mathrm{mg} / \mathrm{L}\right.$, $\mathrm{MnCl}_{2} \cdot 4 \mathrm{H}_{2} \mathrm{O} \quad 0.1 \mathrm{mg} / \mathrm{L}, \quad \mathrm{CoCl}_{2} \cdot 6 \mathrm{H}_{2} \mathrm{O} \quad 0.19 \mathrm{mg} / \mathrm{L}$, $\mathrm{CuCl}_{2} \cdot 2 \mathrm{H}_{2} \mathrm{O} \quad 0.002 \mathrm{mg} / \mathrm{L}, \quad \mathrm{NiCl}_{2} \cdot 6 \mathrm{H}_{2} \mathrm{O} \quad 0.024 \mathrm{mg} / \mathrm{L}$, $\mathrm{H}_{3} \mathrm{BO}_{3} 0.006 \mathrm{mg} / \mathrm{L}, \mathrm{Na}_{2} \mathrm{MoO}_{4} \cdot 2 \mathrm{H}_{2} \mathrm{O} 0.036 \mathrm{mg} / \mathrm{L}$ ). Dissolved oxygen in the medium was boiled for half an hour
Table 3 Strains and primers in this study

\begin{tabular}{|c|c|c|}
\hline & Characteristics & Source \\
\hline \multicolumn{3}{|l|}{ Strains } \\
\hline C. carboxidivorans P7 & $\begin{array}{l}\text { Autotrophic growth on } \mathrm{CO}, \mathrm{CO}_{2} \text {, } \\
\text { and } \mathrm{H}_{2}\end{array}$ & Our lab \\
\hline \multicolumn{3}{|l|}{ Primers $5^{\prime} \rightarrow 3^{\prime}$} \\
\hline RT-PCR-glkF & AGGTACGTGATAAAGCAT & This study \\
\hline RT-PCR-glkR & TGAAACTCCTCCTCCAAT & This study \\
\hline RT-PCR-pfkF & TCCTGAGAAAGGCTACAA & This study \\
\hline RT-PCR-pfk R & ATCTGCTCCACCAATACC & This study \\
\hline RT-PCR-otc F & GAAGAATGGGAAGAACG & This study \\
\hline RT-PCR-otc $R$ & CTGGCAAGCAATGAAGA & This study \\
\hline RT-PCR-ckF & TGAGAAAGGCACTGGAT & This study \\
\hline RT-PCR-ck R & TATGGGTTTAGTTGGAT & This study \\
\hline
\end{tabular}

to eliminate under the stream of $\mathrm{N}_{2}$ gas, then added $\mathrm{L}$-cysteine- $\mathrm{HCl} \cdot \mathrm{H}_{2} \mathrm{O} 0.5 \mathrm{~g} / \mathrm{L}$ and continued to boil for an hour until the color of the medium from blue to colorless. The boiled medium was divided into a serum bottle $(50 \mathrm{~mL} / 100 \mathrm{~mL})$ and nitrogen added for 10 to $20 \mathrm{~min}$, until the color changed from a light blue to yellow. Then serum bottles were sealed with gas impermeable butyl rubber septum-type stoppers and aluminum crimp seals. The serum bottles filled with medium were sterilized at $121{ }^{\circ} \mathrm{C}$ for $20 \mathrm{~min} .500 \mu \mathrm{L}$ sterilized glucose $(500 \mathrm{~g} / \mathrm{L})$ and $250 \mu \mathrm{L}$ sterilized L-cysteine- $\mathrm{HCl} \cdot \mathrm{H}_{2} \mathrm{O}(100 \mathrm{~g} / \mathrm{L})$ were added into media. Before inoculation, the culture medium should be adjusted to $\mathrm{pH} \sim 6.6$ with $1 \mathrm{M} \mathrm{HCl}$ or $1 \mathrm{M} \mathrm{NaOH}$, which was purged with $\mathrm{N}_{2}$ for $10 \mathrm{~min}$ and sterilized. The gas fermentation medium (Syngas-GY free medium): MM520 medium contains no glucose and yeast extract and is filled with the gas mixture $\left(50 \% \mathrm{CO}_{2}\right.$, $35 \% \mathrm{CO}$, and $15 \% \mathrm{H}_{2}$ at $1 \mathrm{~atm}$ ) and it should be purged every $48 \mathrm{~h}$. The gas fermentation medium (N2-GY free medium): MM520 medium filled with the $\mathrm{N}_{2}$ and purged every 2 days, without any glucose and yeast extract added to it.

\section{Fermentation}

All fermentation processes were performed in serum bottles filled with $50 \mathrm{~mL}$ culture medium, and samples were taken at regular intervals for analysis. In order to study the effects of 20 conventional amino acids and citrulline on the growth of $C$. carboxidivorans $\mathrm{P7}$, each amino acid $(1 \mathrm{~g} / \mathrm{L})$ was added to the MM520 medium and placed in a $37{ }^{\circ} \mathrm{C}$ incubator for fermentation. So as to further study the effects of different concentrations of citrulline on the growth of C. carboxidivorans $\mathrm{P} 7$, different concentrations of citrulline $(0.6 \mathrm{~g} / \mathrm{L}, 1.2 \mathrm{~g} / \mathrm{L}, 2.4 \mathrm{~g} / \mathrm{L})$ were added to the fermentation medium. Heterotrophic medium supplemented with $0.6 \mathrm{~g} / \mathrm{L}$ citrulline was named MM520-0.6 
Cit. Syngas fermentation was performed in Syngas-GY free medium. After inoculation at $5 \%(\mathrm{v} / \mathrm{v})$, the serum bottle cells were cultured at $37{ }^{\circ} \mathrm{C}, 150 \mathrm{rpm}$. Syngas-GY free medium supplemented with $0.6 \mathrm{~g} / \mathrm{L}$ citrulline named Syngas-0.6 Cit-GY free medium. All fermentation conditions were performed in duplicate.

\section{Analytical methods}

The spectrophotometer (UV-1800) was used to determine the Optical Density $\left(\mathrm{OD}_{600}\right)$. The specific growth rate $(\mu)$ was measured according to derivative of growth curve of C. carboxidivorans P7. Double time was measured based on the formula ( $\mu=\ln 2 / \mathrm{td}$, where $\mu$ is specific growth rate and td is double time). Acetate and butyrate were analyzed on an HPX-87H column (Bio-Rad). Detection conditions: Temperature $50^{\circ} \mathrm{C}$, Mobile phase: $5 \mathrm{~mm}$ $\mathrm{H}_{2} \mathrm{SO}_{4}$, Detection wavelength: $210 \mathrm{~nm}$, Flow rate: $1 \mathrm{~mL} /$ min. Ethanol and butanol were detected according to Cheng [7]. ATP was measured by ATP Assay Kitae (s0026b) purchased from Beyotime Institute of Biotechnology. All of the assays were performed in triplicate.

\section{Gene expression detection via RT-qPCR}

The total RNA extraction of the collected cells was performed by using FastPure Cell/Tissue Total RNA Isolation Kit RC101(Vazyme Biotech Co., Ltd., Nanjing, China). RT-qPCR reactions were conducted with ChamQ Universal SYBR qPCR Master Mix"Q711-02 (Vazyme Biotech Co., Ltd., Nanjing, China). The StepOnePlus 96 real-time PCR system (Applied biological systems Inc, USA) was used to amplify and quantify the PCR samples. The method was as follows: $30 \mathrm{~s}$ at $95^{\circ} \mathrm{C}, 40$ amplification cycles of $10 \mathrm{~s}$ at $95{ }^{\circ} \mathrm{C}$, and $30 \mathrm{~s}$ at $60{ }^{\circ} \mathrm{C}$. Relative levels of transcript abundance of the studied genes were calculated by the $2^{-\Delta \Delta C T}$ method. RT-qPCR of each gene was tested with three reactions in parallel.

\section{Scanning electron microscopy}

Frozen scanning electron microscopy (FSEM) was used to observe cell morphology of C. carboxidivorans P7 under the medium of MM502 and MM520-0.6 Cit. Bacterial cells were cultured in MM520 and MM520-0.6 Cit medium at $37^{\circ} \mathrm{C}$ incubator for $96 \mathrm{~h}$. Then the bacteria cells were collected by centrifugation at $6000 \mathrm{rpm}$, resuspended with sterile water, and placed on carbon filmcoated copper Grid (230 mesh; Beijing Zhongjing Science and Technology Co., Ltd., Beijing, China). At last, the bacterial cells liquid on the film was dried at $25{ }^{\circ} \mathrm{C}$ and observed by FSEM.

\section{Authors' contributions}

XL preformed all the experimental works, analyzed the data, and coordinated the manuscript draft and revision. TY designed and revised the manuscript critically. RH, TB, and XZ helped with data analysis. TO, MX, and ZR were involved in proofreading the manuscript. All the authors read and approved the final manuscript.

\section{Funding}

This work was supported by the National Key Research and Development Program of China (No. 2021YFC2100900), the Science and Technology Project of Xinjiang Production and Construction Corps (No. 2019AB009), the National Natural Science Foundation of China (No. 30271470, 21778024), National First-Class Discipline Program of Light Industry Technology and Engineering (LITE2018-06), and the Program of Introducing Talents of Discipline to Universities (111-2-06).

\section{Availability of data and materials}

The datasets used and/or analyzed during the current study are available from the corresponding author on reasonable request.

\section{Declarations}

Ethics approval and consent to participate Not applicable.

\section{Consent for publication}

All the authors have read and approved the manuscript before submission to Biotechnology for Biofuels.

\section{Competing interests}

The authors declare that they have no conflicts of interest.

\section{Author details}

${ }^{1}$ The Key Laboratory of Industrial Biotechnology, Ministry of Education, School of Biotechnology, Jiangnan University, 1800 Lihu Road, Wuxi 214122, Jiangsu, China. ${ }^{2}$ Department of Chemical and Biomolecular Engineering, The Ohio State University, Columbus, OH 43210, USA.

Received: 30 July 2021 Accepted: 2 October 2021

Published online: 16 October 2021

\section{References}

1. Henrich E, Dahmen N, Dinjus E, Sauer J. The role of biomass in a future world without fossil fuels. Chem Ing Tech. 2015;87(12):1667-85.

2. Seroussi $\mathrm{H}$. Fate and future climatic role of polar ice sheets. Nature. 2019;566(7742):48-9.

3. Sommer R, Glazirina M, Yuldashev T, Otarov A, Ibraeva M, Martynova L, Bekenov M, Kholov B, Ibragimov N, Kobilov R, et al. Impact of climate change on wheat productivity in Central Asia. Agr Ecosyst Environ. 2013;178:78-99.

4. Shen S, Gu Y, Chai C, Jiang W, Zhuang Y, Wang Y. Enhanced alcohol titre and ratio in carbon monoxide-rich off-gas fermentation of Clostridium carboxidivorans through combination of trace metals optimization with variable-temperature cultivation. Bioresour Technol. 2017;239:236-43.

5. Yu M, Zhang Y, Tang I, Yang S. Metabolic engineering of Clostridium tyrobutyricum for n-butanol production. Metab Eng. 2011;13(4):373-82.

6. Lee SY, Park JH, Jang SH, Nielsen LK, Kim J, Jung KS. Fermentative butanol production by Clostridia. Biotechnol Bioeng. 2008;101(2):209-28.

7. Cheng C, Li WM, Lin M, Yang ST. Metabolic engineering of Clostridium carboxidivorans for enhanced ethanol and butanol production from syngas and glucose. Bioresour Technol. 2019;284:415-23.

8. Abubackar HN, Veiga MC, Kennes C. Production of acids and alcohols from syngas in a two-stage continuous fermentation process. Bioresour Technol. 2018;253:227-34.

9. Fernández-Naveira Á, Veiga MC, Kennes C. Glucose bioconversion profile in the syngas-metabolizing species Clostridium carboxidivorans. Bioresour Technol. 2017;244:552-9. 
10. Lee S, Yun EJ, Kim J, Lee SJ, Um Y, Kim KH. Biomass, strain engineering, and fermentation processes for butanol production by solventogenic clostridia. Appl Microbiol Biotechnol. 2016;100(19):8255-71.

11. Zhu C, Du G, Zhang J, Xue C. A high-efficient strategy for combinatorial engineering paralogous gene family: a case study on histidine kinases in Clostridium. Biotechnol Bioeng. 2021;118:2770-80.

12. Du G, Zhu C, Xu M, Wang L, Yang S, Xue C. Energy-efficient butanol production by Clostridium acetobutylicum with histidine kinase knockouts to improve strain tolerance and process robustness. Green Chem. 2021;23:2155-68.

13. Zampieri M, Hörl M, Hotz F, Müller NF, Sauer U. Regulatory mechanisms underlying coordination of amino acid and glucose catabolism in Escherichia coli. Nat Commun. 2019. https://doi.org/10.1038/ s41467-019-11331-5.

14. Klasson KT, Ackerson MD, Clausen EC, Gaddy JL. Biological conversion of coal and coal-derived synthesis gas. Fuel. 1993;72(12):1673-8.

15. Valgepea K, Loi KQ, Behrendorff JB, Lemgruber RDSP, Plan M, Hodson MP, Köpke M, Nielsen LK, Marcellin E. Arginine deiminase pathway provides ATP and boosts growth of the gas-fermenting acetogen Clostridium autoethanogenum. Metab Eng. 2017;41:202-11.

16. Li N, Yang J, Chai C, Yang S, Jiang W, Gu Y. Complete genome sequence of Clostridium carboxidivorans P7T, a syngas-fermenting bacterium capable of producing long-chain alcohols. J Biotechnol. 2015;211:44-5.

17. Ragsdale SW, Pierce E. Acetogenesis and the Wood-Ljungdahl pathway of $\mathrm{CO}_{2}$ fixation. Biochim Biophys Acta. 2008;1784(12):1873-98.

18. Wood $\mathrm{HG}$. Life with $\mathrm{CO}$ or $\mathrm{CO}_{2}$ and $\mathrm{H}_{2}$ as a source of carbon and energy. Faseb J. 1991;5(2):156-63.

19. Li D, Meng CX, Wu GX, Xie BT, Han YF, Guo YQ, Song CH, Gao ZQ, Huang ZY. Effects of zinc on the production of alcohol by Clostridium carboxidivorans P7 using model syngas. J Ind Microbiol Biot. 2018;45(1):61-9.

20. Abubackar HN, Veiga MC, Kennes C. Biological conversion of carbon monoxide to ethanol: effect of $\mathrm{pH}$, gas pressure, reducing agent and yeast extract. Bioresour Technol. 2012;114:518-22.

21. Kundiyana DK, Wilkins MR, Maddipati P, Huhnke RL. Effect of temperature, $\mathrm{pH}$ and buffer presence on ethanol production from synthesis gas by "Clostridium ragsdalei". Bioresour Technol. 2011;102(10):5794-9.

22. Shen $Y$, Brown R, Wen Z. Syngas fermentation of Clostridium carboxidivoran $\mathrm{P} 7$ in a hollow fiber membrane biofilm reactor: evaluating the mass transfer coefficient and ethanol production performance. Biochem Eng J. 2014;85:21-9.

23. Huang H, Chai C, Li N, Rowe P, Minton NP, Yang S, Jiang W, Gu Y. CRISPR/ Cas9-based efficient genome editing in Clostridium ljungdahlii, an autotrophic gas-fermenting bacterium. Acs Synth Biol. 2016;5(12):1355-61.

24. Kannuchamy S, Mukund N, Saleena LM. Genetic engineering of Clostridium thermocellum DSM1313 for enhanced ethanol production. BMC Biotechnol. 2016. https://doi.org/10.1186/s12896-016-0260-2.

25. Liew F, Henstra AM, Köpke M, Winzer K, Simpson SD, Minton NP. Metabolic engineering of Clostridium autoethanogenum for selective alcohol production. Metab Eng. 2017:40:104-14.

26. Hashimoto SI. Discovery and history of amino acid fermentation. Adv Biochem Eng Biotechnol. 2017;159:15-34.
27. Sawers RG. Amino acid degradation. eLS. 2009. https://doi.org/10.1002/ 9780470015902.a0001388.pub2.

28. Bertsch J, Muller V. CO Metabolism in the acetogen Acetobacterium woodii. Appl Environ Microbiol. 2015;81(17):5949-56.

29. Bao T, Cheng C, Xin X, Wang J, Wang M, Yang S. Deciphering mixotrophic Clostridium formicoaceticum metabolism and energy conservation: genomic analysis and experimental studies. Genomics. 2019;111(6):1687-94

30. Braun K, Gottschalk G. Effect of molecular hydrogen and carbon dioxide on chemo-organotrophic growth of Acetobacterium woodii and Clostridium aceticum. Arch Microbiol. 1981;128(3):294-8.

31. Younesi H, Najafpour G, Mohamed AR. Ethanol and acetate production from synthesis gas via fermentation processes using anaerobic bacterium Clostridium ljungdahlii. Biochem Eng J. 2005;27(2):110-9.

32. Liew F, Henstra AM, Winzer K, Köpke M, Simpson SD, Minton NP. Insights into $\mathrm{CO}_{2}$ fixation pathway of Clostridium autoethanogenum by targeted mutagenesis. mBio. 2016;7(3):e416-27.

33. Jiang W, Zhao J, Wang Z, Yang S. Stable high-titer n-butanol production from sucrose and sugarcane juice by Clostridium acetobutylicum JB200 in repeated batch fermentations. Bioresour Technol. 2014;163:172-9.

34. Bao T, Zhao JB, Li J, Liu X, Yang ST. n-Butanol and ethanol production from cellulose by Clostridium cellulovorans overexpressing heterologous aldehyde/alcohol dehydrogenases. Bioresour Technol. 2019;285: 121316.

35. Richter H, Molitor B, Wei H, Chen W, Aristilde L, Angenent LT. Ethanol production in syngas-fermenting Clostridium ljungdahlii is controlled by thermodynamics rather than by enzyme expression. Energ Environ Sci. 2016;9(7):2392-9.

36. Ramio-Pujol S, Ganigue R, Baneras L, Colprim J. Incubation at $25^{\circ} \mathrm{C}$ prevents acid crash and enhances alcohol production in Clostridium carboxidivorans P7. Bioresour Technol. 2015;192:296-303.

37. Sun X, Atiyeh HK, Kumar A, Zhang HL, Tanner RS. Biochar enhanced ethanol and butanol production by Clostridium carboxidivorans from syngas. Bioresour Technol. 2018;265:128-38.

38. Kelly B, Pearce EL. Amino assets: how amino acids support immunity. Cell Metab. 2020:32(2):154-75.

39. Marcellin E, Behrendorff JB, Nagaraju S, DeTissera S, Segovia S, Palfreyman RW, Daniell J, Licona-Cassani C, Quek L, Speight R, et al. Low carbon fuels and commodity chemicals from waste gases-systematic approach to understand energy metabolism in a model acetogen. Green Chem. 2016;18(10):3020-8

40. Agu CV, Ujor V, Ezeji TC. Metabolic engineering of Clostridium beijerinckii to improve glycerol metabolism and furfural tolerance. Biotechnol Biofuels. 2019. https://doi.org/10.1186/s13068-019-1388-9.

\section{Publisher's Note}

Springer Nature remains neutral with regard to jurisdictional claims in published maps and institutional affiliations.

\footnotetext{
Ready to submit your research? Choose BMC and benefit from:

- fast, convenient online submission

- thorough peer review by experienced researchers in your field

- rapid publication on acceptance

- support for research data, including large and complex data types

- gold Open Access which fosters wider collaboration and increased citations

- maximum visibility for your research: over $100 \mathrm{M}$ website views per year
}

At BMC, research is always in progress.

Learn more biomedcentral.com/submissions 